\title{
ETIKA GURU DAN MURID DALAM TARIKAT SAMMANIYAH
}

\author{
Ahmad Sya'rani \\ Pascasarjana Jurusan Akhlak Tasawuf \\ IAIN Antasari Banjarmasin \\ Diterima tanggal 22 April 2016 / Disetujui tanggal 9 Mei 2016
}

\begin{abstract}
Sheikh Muhammad Samman who love science and adrift heart of the religious sciences, devoted himself to God directly in the path of Sufism. Because of his persistence in the world of mysticism, it leds Sheikh Muhammad Samman to various teachers and sheikhs, until he also founded a new tarikat which is a combination of various tarikat that he followed previously. The emergence of a new tarikat that is based on some tarikat is not new and can be accepted. Surely, he formed a new tarikat called Sammaniyah that have many followers until now. Of his teachings in the tarikat, there are some rules that discussed about relationship between the Murshid or sheikh with a pupil. The concept about it is similar to the relationship between the Prophet with his companions or with some of his followers. From Sirah Nabawiyah, it can be concluded how the Companions of the Messenger had spoken and vice versa as well as he, the Prophet., treats his companions. Actually, this condition applies to every tarikat anywhere.
\end{abstract}

Kata kunci: Etika, tarikat, Sammaniyah

\section{Pendahuluan}

Mengenal Tarikat Sammaniyah tentu tidak asing lagi di telinga kita, terlebih-lebih penduduk Kalimantan Selatan yang mayoritas penganut Tarikat Sammaniyah. Sungguh beruntung orang yang masuk dalam kelompok ini, sehingga bisa menghantarkan dirinya untuk bisa mendekatkan diri kepada Sang Khalik secara cepat dan mudah, dikarenakan pencetusnya adalah orang yang memiliki kelebihan khusus di sisi tuhannya melalui jalan Tarikat Sammaniyah yang bermuatan zikir, wirid dan pembersihan hati untuk mencapai suatu maqam yang terpuji dengan menggabungkan syari'at dan tarikat. ${ }^{1}$

Tulisan ini membahas tentang seluk-beluk Tarikat Sammaniyah, terutama berkenaan dengan etika antara guru dan murid yang diajarkan dalam tarikat tersebut. Pada dasarnya, konsep hubungan guru dan murid yang berlaku dalam Tarikat Sammaniyah itu mengacu pada pengajaran yang dicontohkan Nabi Muhammad Saw. dalam hubungannya dengan sahabat-sahabat dan pengikutpengikut beliau. Penulis menggarisbawahi beberapa aturan yang harus ditaati oleh pengikut Tarikat Sammaniyah ketika itu berhadapan dengan sang guru atau dengan murid.

\section{Biografi Syekh Muhammad Samman}

Nama lengkap beliau ialah Muhammad bin 'Abd al-Karim al-Madani as-Syafi'i as-Samman.' Pada literatur yang lain ada penambahan di belakang nama beliau menjadi Muhammad bin 'Abd alKarim as-Samman al-Madani al-Khalwati al-Qadiri as-Syadzili as-Syafi’i (1130-1189 H/1718-1775 
M). Beliau termasuk dari keturunan keluarga dari kaum Quraisy. Beliau memiliki kunyah yaitu Abu Abdillah. Namun beliau lebih dikenal dengan sebutan Syekh Muhammad Samman. ${ }^{3}$

Gelar as-Samman (pedagang mentega) diberikan oleh para muridnya. Ketika mereka kehabisan makanan, Syekh Samman menurunkan sebuah ember ke dalam sumur, kemudian ember tersebut muncul dengan dipenuhi mentega. Berikut gelar-gelar yang disematkan kepada beliau yaitu "al-Waliy al-Kamil Mukammil (seorang wali yang sempurna lagi menyempurnakan), Khatam Abl alIrfan (Penutup para ahli makrifat), Ustadz al-A'sham (Guru besar), Quthb al-Akwan (Poros alam), Gawts az-Zaman (Penolong zaman), al'Arif billah (Orang yang kenal dengan Allah), Sayyid Syekh Muhammad Samman Al-Madani”.

Syekh Muhammad Samman lahir dan wafat di kota Madinah. Beliau menghabiskan hidupnya di kota Madinah. Beliau tinggal di rumah bersejarah milik sahabat Rasulullah saw yaitu Abu Bakar alShiddiq. Semenjak kecilnya Syekh Muhammad Samman senang belajar agama kepada para ulama sekitar Madinah dan saat usia delapan tahun beliat telah hafal al-Qur'an. Saat menginjak masa remaja, beliau sudah menjadi guru agama pada Madrasah Sanjariyah di Madinah dan didatangi banyak murid dari negeri yang jauh.Namun begitu, beliau tetap belajar kepada para ulama di zaman itu.

Syekh Samman wafat pada hari Rabu, waktu Dhuha (antara pukul 06.30-10.00) pada tanggal 02 Dzulhijjah tahun 1189/1775 M. Beliau wafat di usia 57 tahun dan sempat sakit selama 17 hari. Beliau dimakamkan di pemakaman Baqi', Madinah. Ini merupakan tempat para istri Nabi Muhammad Saw. dan para sahabatnya dimakamkan. ${ }^{4}$

Syekh Muhammad Samman menimba ilmu dalam bidang hukum Islam kepada Muhammad al-Daqqaq, Sayyid 'Ali al-'Aththar, 'Ali al-Kurdi, 'Abd al-Wahhab at-Thanthawi (di Makkah) dan Said Hilal al-Makki. Guru dalam bidang ilmu Hadis yang juga seorang Muhaddits bernama Muhammad Hayyat, yang merupakan penganut Tarikat Naqsabandiyah. Guru-guru beliau yang lain seperti Muhammad Sulaiman al-Kurdi (1125-1194 H/1713-1780 M), Abu Thahir al-Kurani, 'Abd Allah alBashri dan Musthafa bin Kamal ad-Din al-Bakri (1099-1163 H/1688-1749 M). Musthafa bin Kamal ad-Din al-Bakri ialah guru pada bidang tasawuf dan tauhid. Beliau berasal dari Damaskus, menetap di Madinah dan wafat di Kairo, Mesir tahun 1749. Beliau seorang ulama yang produktif dan juga seorang Syaikh tarikat Khalwatiyah. Ada dua Syaikh Tarikat Khalwatiyah yang juga menjadi guru dari Syekh Muhammad Samman yaitu Muhammad bin Salim al-Hifnawi dan Muhammad al-Kurdi, namun pengaruh dari kedua guru ini tidak nampak pada karya-karya Syekh Muhammad Samman.

\section{Sejarah dan Perkembangan Tarikat Sammaniyah}

Tarikat Sammaniyah dicetuskan oleh Muhammad bin 'Abd al-Karim as-Samman al-Madani al-Khalwati al-Qadiri as-Syadzili as-Syafi'i. Penamaan tarikat ini dinisbahkan kepada nama beliau oleh para muridnya. Sedangkan Syekh Muhammad Samman menamai tarikat yang didirikannya ini dengan al-Mubammadiyah yang berarti jalan Nabi Muhammad. ${ }^{5}$

Dari pemaparan sebelumnya telah diuraikan bahwa Syekh Muhammad Samman haus akan ilmu sehingga beliau menimba ilmu kepada banyak guru. Termasuk pengembaraannya pada beberapa

${ }^{3}$ Abdul Basit, Syekh Muhammad Samman dan Ulama-Ulama Jawi Abad XVIII; Tarekat, Manaqib, dan Propagandis Syekh Samman al-Madani, cet. ke-2 (Kapuas Timur: Ulin Global Press, 2010), 1.

${ }^{4}$ Abdul Basit, Syekh Muhammad Samman dan Ulama-Ulama Jawi Abad XVIII; Tarekat, Manaqib, dan Propagandis Syekh Samman al-Madani, 4-5.

${ }^{5}$ Bandingkan Abdul Basit, Syekh Muhammad Samman dan Ulama-Ulama Jawi Abad XVIII; Tarekat, Manaqib, dan Propagandis Syekh Samman al-Madani, 5-10 dengan Sri Mulayati (dkk.), Mengenal dan Memahami Tarekat-Tarekat Muktabarah di Indonesia, 182-183. 
tarikat yang memberikan pengaruh yang kental pada Tarikat Sammaniyah nantinya, seperti Tarikat Khalwatiyyah dengan Syaikh Musthafa bin Kamal ad-Din al-Bakri. Kemudian beliau juga belajar Tarikat Naqsabandiyyah dan Tarikat Qadariyyah, sehingga beliau dikenal dengan nama Muhammad bin 'Abd al-Karim al-Qadiri as-Samman pada zaman itu. Pengaruh tokoh besar dari tarikat ini yaitu 'Abd al-Ghani an-Nabulusi, seorang ulama produktif dan pembela Ibn al-'Arabi dan 'Abd al-Karim al-Jilli, (w 1143/1731) yang juga guru dari Musthafa bin Kamal ad-Din al-Bakri sangat signifikan pada diri Syekh Muhammad Samman. Syekh Muhammad Samman juga belajar pada Tarikat Syadziliyyah yang mewakili tradisi tasawuf Magribi dan dikenal dengan biz̨ib-hiæibnya

Dari keempat tarikat tersebut, Syekh Muhammad Samman meramu dan memadukan teknikteknik zikir, bacaan-bacaan dan ajaran mistis semua tarikat tersebut dengan tambahan seperti qasidah dan bacaan lain yang beliau susun sendiri). Dengan kata lain Tarikat Sammaniyah atau Tarikat alMuhammadiyah ini merupakan perpaduan dari berbagai tarikat yang pernah dipelajari oleh Syekh Muhammad Samman dan juga merupakan hasil akulturasi tradisi dari berbagai belahan dunia yang dibawa oleh para murid yang belajar padanya.

Persinggungan tradisi yang disebutkan di atas diperoleh beliau dari jabatan beliau sebagai penjaga pintu makam Nabi Muhammad Saw., beliau menerima para peziarah dari seluruh penjuru dunia dengan tradisi yang berbeda-beda. Para murid beliau yang berasal dari berbagai benua, dari Magribi dan Afrika Timur, India sampai ke Indonesia. Beliau menemukan lahan subur atas ketertarikannya terhadap tradisi-tradisi dari para muridnya. Inilah mungkin salah satu karunia Tuhan dari posisinya sebagai penjaga makam Nabi Muhammad Saw.

Penggabungan berbagai tarikat dan melahirkan tarikat baru bukanlah hal yang baru pada dunia tasawuf. Sebut saja Muhammad 'Utsman al-Mirghani memadukan Tarikat Naqsabandiyyah, Qadariyyah, Syadziliyah, Junaidiyyah dan Mirganiyyah sehingga lahir Tarikat Khatmiyyah. Tarikat ini menyebar di wialayah Afrika Timur. Kemudian Ahmad Khatib Sambas, seorang ulama Kalimantan yang menetap di Makkah menggabungkan Tarikat Qadiriyyah dan Naqsabandiyyah, Tarikat al-Anfas, Tarikat al-Junaidiyyah, dan Tarikat Muwafaqah menjadi Tarikat Qadiriyyah wa Naqsabandiyah. Tarikat inilah yang menggantikan kepopuleran tarikat Sammaniyah di Indonesia.

\section{Ajaran Tarikat Sammaniyah}

Ajaran tarikat Sammaniyah merujuk pada kitab Syekh Muhammad Samman dengan judul anNafahat al-Ilabiyyah. Kitab ini terdiri delapan bab yaitu taubat, baiat, zikir, khalwat, penyakit hati, persaudaraan, adab kepada guru, wali dan penutup tentang nasihat kepada ikhwan. ${ }^{6}$

Zikir Sammaniyah adalah jahr (keras) dengan lafaz nafi istbat, yaitu La ilaha illa Allah. Lafaz yang afdal sesuai dengan hadis Afdhal adz-dzikir La Ilaha Illal-Lah. Adapun dalil keutamaan zikir jahr, yaitu riwayat Ibnu Abbas bahwa masa Nabi saw zikir dilaksanakan setelah jamaah selesai salat fardu. Manfaat zikir jahr antara lain menampakkan syi'ar Islam, memberi berkah pada pendengarnya, menghapus dosanya dan menumbuhkan iman. Zikir jahr bagaikan tukang besi yang memukul palunya untuk menghilangkan karat yang melengket pada besi.Begitu pulaorang yang berzikir jabr dapat menghilangkan dosa yang melekat dalam hati.

Pengikut tarikat Sammaniyah di Sulawesi Selatan memodifikasi zikir dengan membagi zikir menjadi sikkiri seppulo (zikir sepuluh) dan sikkiri tellu ratu (zikir 300). Zikir sepuluh dilaksanakan dengan sir (tidak keras) dalam situasi seperti musafir, sakit atau berada di tempat yang dapat 
mengganggu orang lain. Zikir tiga ratus atau zikir jahr dilaksanakan dua kali yaitu sesudah shalat Ashar dan Isya.Lamanya sekitar sepuluh menit dengan perubahan lafaz mulai La Ilaha Illal-Lah, kemudian Allah Allah, dan terakhir Huwa Huwa.Adapun tarikat Sammaniyah yang berkembang atau berasal dari Sumatera Barat, zikir jahr dilaksanakan setiap selesai salat fardu.

\section{Adab Murid Terhadap Guru}

Hubungan antara mursyid atau syekh dengan murid dalam tarikat zikir Samman seperti hubungan antara Nabi Saw. dengan para sahabat beliau atau dengan para umatnya. Hal ini berlaku pada setiap tarikat manapun. ${ }^{7}$ Dari sirah nabawiyah, kita telah mengetahui bagaimana sikap para sahabat bertutur kata kepada Rasulullah Saw. dan begitupun juga sebaliknya beliau, Rasulullah saw., memperlakukan para sahabat beliau saw.

Allah Swt. telah berfirman di dalam al-Qur'an tentang para sahabat Nabi Muhamamd Saw. apabila berbicara kepada Nabi Muhammad Saw. tidak boleh dengan suara yang lebih nyaring atau lebih keras dari suara nabi Muhammad sendiri. Terdapat pada surah al-Hujurat ayat 2 yang berbunyi:
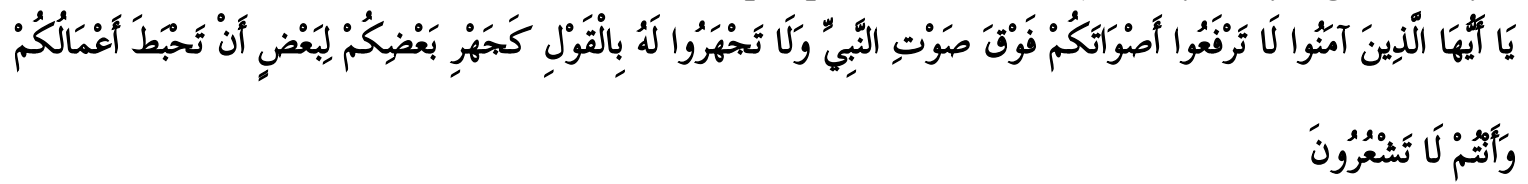

"Hai orang-orang yang beriman, janganlah kamu meninggikan suaramu melebibi suara nabi, dan janganlah kamu Berkata kepadanya dengan suara yang keras, sebagaimana kerasnya suara sebagian kamu terbadap sebagian yang lain, supaya tidak hapus (pahala) amalanmu, sedangkan kamu tidak menyadari”.

Ketika seorang murid tarikat yang akan melakukan suluk disebut Salik. Ibn Arabi memberi petunjuk dalam salah satu naskah yang berjudul at-Tadbiratu al-llabiyat fi Islabi al-Mamlakati al-Insaniyat tentang adab seorang salik terhadap gurunya dalam tarikat berikut ini:

1. Salik bersikap di hadapan gurunya seperti seorang mayat yang berada di tangan para orang yang akan memandikannya. Terserah kepada para pemandi jenazah bagaimana mereka memperlakukan jenazah tadi. Begitu juga salik, dia menyerahkan sepenuhnya kepada gurunya tanpa melakukan protes sedikitpun.

2. Salik juga tidak boleh ada terlintas sedikitpun dalam hati dan pikirannya prasangka buruk atau keraguan terhadap gurunya. Dia harus menjaga hati dan pikirannya bersih dari prasangka buruk kepada gurunya walaupun bagaimanapun tingkah laku seorang guru itu berlawanan syariat. Allah Swt memerintahkan kita untuk menghindarkan diri dari prasangkaprasangka buruk kepada sesama manusia. Terlebih bagi salik untuk menghindari prasangka buruk atau keraguan kepada gururnya.

3. Salik tidak boleh menempati bagian tempat duduk yang biasanya diduduki oleh gurunya dan apabila dia ingin duduk, dia tidak boleh duduk di depan gurunya (membelakangi gurunya).

4. Salik tidak boleh memakai barang yang biasanya dipakai oleh gurunya.

5. Salik harus bersegera melaksanakan pekerjaan yang disuruh oleh gurunya dan tidak boleh mengajukan usul apapun karena dia belum mengerti atau tidak tahu tentang jenis pekerjaan itu.

${ }^{7}$ Ahmad Purwadaksi, Ratib Samman dan Hikayat Syekh Mubammad Samman: Suntingan Naskah dan Kajian Isi Teks, (Jakarta: Djambatan, 2004), 357-358. 
6. Salik tidak boleh menanyakan kemana gurunya ingin pergi apabila bertemu dengannya di tengah perjalanan.

7. Salik tidak boleh menikahi janda dari gurunya apabila suami (gurunya) meninggal atau bercerai (Nyberg, 1919: 226-227)

8. Salik tidak boleh memberikan kritik apapun kepada gurunya. Ibnu 'Arabi dalam bukunya alFutuhat al-Makkiyyat menjelaskan bahwa ekspresi-ekspresi sufi seperti tertawa, senyum, terkejut, ragu-ragu, benci, cinta, suka atau cenderung akan sesuatu semuanya itu langsung datang dari Allah sebagaimana terjadi dengan para nabi Allah Swt. (Takeshita: 126).

Yusuf Makasar dalam naskahnya an-Nafkhatu as-Sailaniyat menjelaskan bahwa seorang murid yang berani melawan gurunya dalam sebuah tarikat berarti sama dengan melawan Allah. Gurunya tersebut bersama dengan Allah dan ia berdiri dengan maz̧hariyat Allah. Seorang murid tidak boleh berdiskusi, menentang atau menyanggah nasihat-nasihat gurunya. Ia wajib menjaga adab dan hormatnya kepada gurunya. Apabila ia tidak hormat dan taat kepada gurunya, maka hancurlah adabnya kepada Nabi Muhammad Saw. sebab guru merupakan wakil nabi Muhammad Saw. dalam hal kepemimpinan rohani sampai di hadirat Tuhan.

Syaikh ‘Abdul Qadir Isa memaparkan akhlak murid kepada gurunya ialah sebagai berikut:

1. Murid harus pasrah kepada mursyidnya dalam semua perintah dan nasihatnya.

2. Murid tidak boleh menentang kepada mursyidnya dalam pendidikan yang didapatnya.

3. Murid tidak boleh meyakini bahwa mursyidnya adalah seorang yang maksum seperti para

Nabi dan Rasul, meskipun mursyidnya memiliki konidisi yang sempurna namun tidak maksum.

4. Murid harus yakin terhadap kesempurnaan kompetensi mursyid dan bimbingannya.

5. Murid harus bersikap jujur dan ikhlas dalam bergaul dengan mursyidnya.

6. Murid harus mengagungkan mursyidnya dan menjaga kehormatannya.

7. Murid harus mencintai urysidnya dengan cinta yang maksimal.

8. Murid tidak boleh berpaling kepada mursyid yang lain.

9. Murid menjaga ketenangan majlis mursyidnya.

10. Murid bergegas dalam membantu keperluan mursyidnya.

11. Murid harus senantiasa hadir dalam majlis mursyidnya

12. Murid harus bersikap terhadap atas sika-sikap mursyidnya.

13. Murid hendaknya tidak menyampaikan ucapan-ucapan murysidnya kepada orang lain kecuali sesuai kadar pemahaman dan nalar mereka. ${ }^{8}$

Nabi Muhammad Saw. mampu memberikan syafaat atau pertolongan kepada umat-umat beliau yang berdosa di hari kiamat kelak. Beliau bersabda bahwa syafaat-nya pada hari kiamat itu adalah hak bagi umatnya yang berdosa dan tidak berhak memperolehnya mereka yang tidak mempercayainya (as-Suyuthi jilid II, t.t.: 40).

Syekh Muhammad Samman adalah sufi dan wali Allah swt, hati beliau bersih karena diasah dengan zikir kepada Allah, sehingga ia mampu merekam "wewenang memberi syafaat" dari Nabi Muhammad Saw. ia berkata bahwa ia akan memberi syafaat kepada murid-muridnya yang percaya kepadanya pada hari kiamat nanti. Ia berkata pula bahwa mempunyai kemampuan untuk menolong dan memberikan Syafaat. Sehingga, orang yang bersangkutan merasa aman.

${ }^{8}$ Syaikh 'Abdul Qadir Isa, Hakekat Tarikat, terj. Khairul Amru Harahap dan Afrizal Lubis, (Jakarta: Qisthi Press, 2005), 1-63 


\section{Penutup}

Berdasarkan paparan di atas dapat kita ambil benang merah bahwa Syekh Muhammad Samman lahir dari keluarga yang cinta akan ilmu dan mengabdikan dirinya di jalan allah swt. Hal ini memberikan pengaruh pada kehidupan Syekh Muhammad Samman yang cinta ilmu, terpaut hatinya ilmu-ilmu agama dan mengabdikan dirinya kepada Allah swt dalam jalan tasawuf.

Ketekunannya dalam dunia tasawuf menuntun dirinya kepada berbagai guru dan syekh, hingga dia pun mendirikan sebuah tarikat yang merupakan kombinasi dari berbagai tarikat yang beliau ikuti sebelumnya.Kemunculan sebuah tarikat baru yang didasari dari beberapa tarikat adalah bukan hal yang baru dan dapat diterima.

Syekh Muhammad Samman sangat memperhatikan terhadap etika murid kepada gurunya berikut ini:

1. Murid berpasrah terhadap apapun nasihat dan petunjuk yang diberikan oleh guru kepada muridnya.

2. Murid harus bersih hati dan bebas berprasangka buruk terhadap gurunya.

3. Murid tidak boleh menempati tempat yang sering digunakan oleh gurunya.

4. Murid tidak boleh memakai barang yang dipakai oleh gurunya.

5. Murid bersegera melaksanakan perintah dari gurunya tanpa mengajukan pertanyaan, usulan ataupun sanggahan.

6. Murid tidak boleh bertanya perihal tujuan kepergian gurunya

7. Murid tidak boleh menikahi janda dari gurunya.

8. Murid tidak boleh mengkritik terhadap tingkah dan perbuatan gurunya, karena dia belum mengetahui perihal perbuatan gurunya.

Hal-hal yang diperbuat oleh guru atau Syekh dalam sebuah tarikat ialah petunjuk dari Allah swt. Inipun berlaku pada Syekh Kamil []

\section{DAFTAR PUSTAKA}

Mulayati, Sri.et.al., Mengenal dan Memahami Tarekat-Tarekat Muktabarah di Indonesia. Jakarta: Kencana. 2005.

Basit, Abdul. Syekh Mubammad Samman dan Ulama-Ulama Jawi Abad XVIII; Tarekat, Manaqib, dan Propagandis Syekh Samman al-Madani.cet. ke-2. Kapuas Timur: Ulin Global Press. 2010.

Purwadaksi, Ahmad. Ratib Samman dan Hikayat Syekh Mubammad Samman: Suntingan Naskah dan Kajian Isi Teks, Jakarta: Djambatan. 2004.

Isa, Syaikh 'Abdul Qadir. Hakekat Tarikat. terj. Khairul Amru Harahap dan Afrizal Lubis. Jakarta: Qisthi Press. 2005. 